\title{
The Antimodern Manifesto of the Rural Flaneur: When D'Arcy and John Go For a Wander
}

\author{
MIKE GRIMSHAW
}

\section{The flaneur \& the landscape of modern life}

'To walk is to lack a place. It is the indefinite process of being absent and in search of a proper.' 1

Central to the self-definition of modernity walks the flaneur, the modern, observing, critical individual who wanders amidst but against the crowds and urban flows of modern life. Central to the flaneur is an identity that is incomplete, an existence that is dissatisfied. ${ }^{2}$ As Bauman notes, the flanuer is the mirror-image, the imitation, the product of the stocktaking, the forced adjustment and mimicry of the modern world - which is itself the original flaneur. ${ }^{3}$ The flaneur occurs in tandem and in response to the rise of the modern city. For the modern city became the exilic, nameless, empty, shifting space and place that was traditionally the realm of the desert and the wilderness. One went alone to the desert, the wilderness, to the empty spaces to find one-self, to discover and encounter truth and meaning - and once upon a time God. Today however the desert of modernity has come to us: it begins outside our front door. In opening the front door, in walking out into the constantly shifting desert of modern life, in confronting the city, the flanuer confronts themself. Their response is to undertake what can be termed a redemptive process involving, as Gleber notes, a central impulse to 'write, register and redeem what has been seen. ${ }^{4}$

It was the German-Jewish critic and intellectual Walter Benjamin who in his unfinished masterpiece The Arcades Project positioned the flaneur as central to the analysis and experience of modern life. Drawing on Baudelaire's identification of the flaneur as a distinctly modern and urban figure, Benjamin appropriated the already-extinct figure of the nineteenth-century Parisian whimsical stroller as the critical position for an engagement with modern life. Following Benjamin's re-positioning, the flaneur wanders now as much through and against ideas and texts as they do the physical experience of the modern city. In thinking what this means for the question of 'Man Alone', drawing on Benjamin the experience of the landscape of modernity becomes central to its reimagining: 'Landscape that, in fact, is what Paris becomes for the flaneur. Or, more precisely: the city splits for him into its dialectical poles. It opens up to him as a landscape, even as it closes around him as a room. ${ }^{5}$

This engagement with landscape is often overlooked in discussions of the flaneur and yet it offers rich possibilities for re-thinking and relocating the discussion of the flaneur into a reassessment of New Zealand literary culture. For landscape is the constant trope, experience, and back-drop location for so much of our literary and cultural reimagining. Yet we must remember too that New Zealand is a highly urbanized society and was so from the early days of the twentieth-century. The landscape, rural myth of New Zealand is a type of Potemkin identity for what was and is a highly urbanized society. This was especially so for the European population, for even in ' 1926 over a third of the population lived in the four main cities and nearly half the population lived in towns larger than $8000 .{ }^{6}$ We should always remember that with $86 \%$ of our population urban, we are more urban than France (85\%), Netherlands (83\%), United States (82\%), United Kingdom $(80 \%)$, Germany (74\%) Italy (68\%) and Japan $(67 \%){ }^{7}$ 


\section{Re-theorizing the flaneur}

This article relocates the notion of the flaneur from a figure in the landscape of modernity into an antimodern experience in the landscape of New Zealand. The centrality of landscape for a modern, urban society exposes the notion, still lurking strongly in many urban minds, of New Zealand as Arcadia. Here we echoed the American experience, by overcoming a sense of dislocation with promotion of this-location: 'Innocent of history and unsure of its culture, America turned to its landscapes as a unique possession to which its response could give meaning and value., 8

In New Zealand, this often became expressed in what Francis Pound described as 'the Nationalist refusal of the city and the Nationalist worship of rurality. ${ }^{9}$ In fact for New Zealand landscape has become what can be termed geopiety '...that curious mix of romantic imagination, historical rectitude and attachment to a particular place. ${ }^{, 10}$

The alternative to such limitations is to follow what, reading from McKenzie Wark, I could term 'flanerie knowledge': 'To refuse to develop knowledge within a category. Knowledge should be botched not batched. The discipline of indiscipline, making tracks, not monitoring borders.' 11 This, I propose, has to occur alongside what Stephen Turner terms 'frontier knowledge': 'For the frontier is the first and last place to know: the first to confront the new, the not-yet-known, and the also to understand what it means, how it is understood in the most general sense, theorized, and returned to the margin., ${ }^{12}$ Such positions can be seen to combine in a contemporary, rethinking of the Benjaminesque flaneur: 'He was the protest of spirit in the face of encroaching materialism, of human time in the face of artificial acceleration. Thus, he made a cult of the materially useless. His prized possession was the observation, the insight. ${ }^{\text {, }}$

Reading out of Benjamin, flanerie is also to put oneself at odds with where one is, to involve oneself in what Benjamin terms "dialectic flanerie: on the one side, the man who feels himself viewed by all and sundry as a true suspect and, on the other side, the man who is utterly undiscoverable, the hidden man."14 We must also remember for Benjamin and all who follow in his wake, that 'Benjamin's flaneur is a motif, a concept in many ways different from the historical flesh-and-blood stroller who wandered the boulevards and passages of 19th century Paris. ${ }^{, 15}$ It is also important to further remember 'Benjamin's flaneur is a response to a world in which sense is disjected, scattered, crystallized in detail. The flaneur is the collector and connoisseur of detail. He is a sensibility as opposed to an intelligence. ${ }^{, 16}$ Therefore, as the careful reader will note, central to our engagement with the flaneur, in this place, in this context of New Zealand is the need to remember what we may have conveniently forgot.

\section{The antimodern, rural flaneur?}

But what happens when the theory of the modern flanuer encounters local theory and an only-partially-reflective local practice? ${ }^{17}$ For despite Pakeha being, for well over a century, an overwhelmingly urban, or at least suburban, people, the Pakeha flaneur has never really been an urban, modern figure. Instead much of Pakeha culture's engagement with modernity has been antimodern with the attendant, alternative figure of what I term the antimodern flaneur who rejects the towns and cities and goes rural: an exile, a searching, wandering, critical figure walking the coastlines and inland byways of New Zealand, situating themselves against the towns and their limitations, their imitations of modern, urban life. While the traditional and normative use of the flaneur has been as an urban figure in an urban environment, I wish to raise its antipodean inverse of the antimodern, rural flaneur as a distinctly New Zealand contribution. The heritage of such figures may seem more linked to the Romantic and Gothic wanderer, or even further back 
to the prophet and pilgrim. ${ }^{18}$ But I wish to argue that the antimodern rural flaneur is one who, as a product of modernity, of urban modernity, takes the position and challenge of the flaneur and wanders in and through 'landscape'; responding to 'landscape' as if it is the modern urban imaginary.

If for the modern flaneur the city became the landscape of new hope and discovery, for the antimodern flaneur the limitations of antipodean urban life were counter-posed by the possibility of a new hope and discovery in the rural landscape. Here we must also remember that landscape is a modern, urban creation. Donald Meinig states: 'Landscape is defined by our vision and interpreted by our minds. It is a panorama which continuously changes as we move along any route. Strictly speaking we are never in it, it lies before our eyes and it becomes real only as we become conscious of it. ${ }^{19}$

The New Zealand art critic, Francis Pound, in a somewhat controversial text on landscape in New Zealand, used the term 'Frames on the Land. ${ }^{20}$ That is, when confronted by a scene, or a collection and interplay of 'natural' and 'human-made' objects, with vantage point, weather and light interacting, we place a 'pictorial frame' around it. We 'see' it as a pictorial whole, we create an image of what we are seeing, in our minds. It becomes an image more than just a play of phenomena: Landscape, or Place is created. As David Wyatt wrote on 'Place', it is '... the stopped frame in the continuous film of change. ${ }^{21}$

The antimodern flaneur moved and continues to move amongst the landscape seeking that which elsewhere they may have sought in the city. The limitations of New Zealand urban life do not seem to offer the possibilities of redemption to the flaneur as they may do elsewhere. Instead, in New Zealand, the antipodean flaneur is predominantly the antimodern flaneur, the rural flaneur who goes once again into the wilderness because the urban spaces are seen as places and spaces of limitation and constriction. For example, in 1931 poet, critic and antimodern provocateur A.R.D. Fairburn wrote from London to a fellow poet and Auckland resident Ron Mason that:

I simply can't live in Auckland again ... They are busy imitating all the time- either their grandmothers, or some imaginary and ludicrous English or Continental model. They're all Baptists at heart, and thoroughly vulgar. I want to live a life in New Zealand in some place where there is life. A really dirty, tough hole like Taumarunui, for instance. Or in some more or less isolated place where I can make a life of my own. Grow fruit or something. ${ }^{22}$

(Of course we should remember Fairburn ended up living the rest of this life in Auckland, on the North Shore, but he did undertake prodigious walks across and within the city. The antimodern, rural flanuer is therefore as much an attitude as an action or activity).

Here it is important to remember the observation and connection made by Geoffrey Hartman that opens up a space for reassessing local practice and local theory:

The flaneur, Benjamin once wrote, is the priest of the genius loci when that genius has lost its sacred and unique place, when it has become a wandering spirit or homeless voice. It is in the air as a startling image: the poem, then, or Baudelaire's quasi-priestly activity is to recover and inscribe these exilic images, to restore spirit to place, if only in poems. ${ }^{23}$

\section{Cresswell: antimodern priest of the genius loci?}

Exemplifying the antimodern flaneur is D'Arcy Cresswell (1896-1960): poet, essayist, self-promoter, incessant wanderer. Often overlooked because as an aestheticzed 
reactionary he seemingly stood so opposed to both cultural nationalism and its later rejection and reassessment, he has undergone a type of rehabilitation, being described by Patrick Evans as that 'snobbish poetaster-tramp ... seen now to stand near the centre of his country's literary culture in his time. ${ }^{24}$ Born in Christchurch, Cresswell turned his back on the 'Philistines of the plains', memorably dismissing New Zealand and especially Canterbury provincial towns and cities as a 'Dead Sea of Bad business' and the location of a 'little Sodom of suburban shortcomings by the coast'. ${ }^{25}$ Cresswell, as one always ready to mythologize time and place, in a letter of 1923 makes a claim of personal distinction situating himself as the first New Zealander: one who is in exile from both England and its ersatz urban, suburban experience in New Zealand. For Cresswell claims a new start and a new perspective as the European New Zealander born here who feels located yet dislocated. This I argue is a particular type of indigeneity that will come to be expressed as the antimodern Pakeha: 'I am a New Zealander. I endeavour to say it simply, with no challenging idealism. I believe I am the first New Zealander. Someone has to be, and of course the last shall be first. ${ }^{26}$

Such indigeneity is different from those in the present day who choose to call themselves 'New Zealander'. It is also an indigeneity that is more nuanced, reflective and in expression opposed to the generics and exclusions of a contemporary 'European' New Zealander claim and identity. The indigeneity of Cresswell was a claim of identity positioned in tension to the prevailing European settler New Zealand culture. Today, antimodern Pakeha identity, in the wake of Cresswell's nuanced and oppositional indigeneity is a claim of identity expressed within and yet against a European New Zealand identity. For Cresswell's indigeneity was a critical one, perhaps a type of cosmopolitan identity that looked both here and abroad for meaning, because Cresswell was torn between the land he was born into and the culture he felt separated from. The struggle to reconcile the two was, and still is, a major component of antimodern Pakeha identity. For the claim, label and indeed idea of Pakeha, arising as a condition of modernity, is accompanied by those expressions of modernity that are angst, doubt, the struggle of the enlightenment and rationality, the search for meaning and location requiring the engagement with the past and yet recognizing the need for a new expression and identity in the new context. In short, being Pakeha, as a condition of modernity, struggles with the collapse of foundational claims and experiences and seeks in turn to express a new, interpretative non-foundational identity arising out of self-reflexivity. John Mulgan, even more so than Cresswell, struggled to express what it meant to be Pakeha. Yet the claims of appropriation that were made posthumously, misleadingly situate his understanding of Pakeha as the man alone indifferent to culture and society. Cresswell by contrast, had the greater impact, becoming a manifesto source for cultural nationalists. This culminates when Curnow quotes appreciatively from Cresswell in his introduction to the 1960 Penguin anthology, claiming Cresswell's verse 'contains some of the best insights by a modern New Zealander writing about his country. ${ }^{, 27}$ Brasch it must be noted, was not so keen, stating that while he had 'been excited and moved to sympathy' by The Poet's Progress, he had hated Present Without Leave, terming it 'unreadable, trivial, uninformed ... [an] image of a wasted life-like my own'. ${ }^{28}$

Cresswell saw himself as living an antimodern life noting that 'by birth I belong to the most wild and rugged of lands, and to the most remote, and my mind, at source, is not cityfed'. ${ }^{29}$ Further, as stated in his dedication to Ormond Wilson of Present Without Leave, he did not believe in 'Socialism, machines, science or a Copernican universe ... it's my job to smash it to bits if I can. ${ }^{30}$ This 'smashing to bits' of what he saw as the failure of modern New Zealand occurs because, as outlined in Present Without Leave, he experiences 'two distinct countries ... on the one hand a social entity wherein I had no place, and on the 
other a wild and half-supernatural ordination whereof I seemed to myself to be the only inhabitant ... [aiming] to unsettle the country and settle it anew by myself. ${ }^{31}$

\section{The antimodern}

Cresswell's life, outlook, tastes and rural wanderings all position him as antimodern because as Arthur Versluis has romantically argued: 'antimodernism is fundamental to the creative impulse in modernity.' Furthermore, 'modern industrial society in its very nature calls forth antimodernism in the creative individual. ${ }^{32}$ Central to antimodernism is a claim of societal and cultural decline that stands opposed to modernity's belief in progress and its linking of socio-economic improvement with the development of technology. As outlined by Versluis, for the antimodernist technological and industrial progress comes at the cost of destructive consequences in nature, culture and religion. It is not surprising that antimodernism took hold as a defining characteristic in New Zealand. For this was, and still strongly imagines itself, a society that exists amidst, and because of, rapid changes to nature - in effect rural industrialization. Yet it was also a society that always felt itself ersatz to Britain, whereby religion was made voluntary and culture deemed only imported. It is therefore also not surprising that, following Cresswell's death in 1960, Charles Brash eulogized Cresswell in terms that can be seen to locate him as antimodern; that is as antimodern in defiance of the emergent modern New Zealand. For Cresswell, according to Brasch was what could be termed, in both cultural and sexual terms, the inverse New Zealander; what we could term perhaps the first antipodean 'New Zealander': an 'eloquent contradiction of everything New Zealand then put its faith in, the New Zealander in reverse. ${ }^{33}$

\section{The antimodern manifesto moment}

Cresswell's antimodernism, while in his mind most clearly presented in his verse, was in its impact far more widely disseminated in his prose, specifically in what I term his antimodern manifestos of The Poet's Progress and Present Without Leave. John Mulgan grew up with Cresswell as part of his father's circle of literary friends and hangers-on, for Alan Mulgan published Cresswell in the Auckland Star when it was claimed his articles for the Press caused such uproar that their publication was discontinued. Cresswell also often stayed with the Mulgan family, considering himself so much an insider that once, finding himself penniless in Wellington, he broke into the Mulgan's empty house, staying for a week by himself, noting 'as in the case of such liberal and kind friends I knew I might, writing to tell them I was there. ${ }^{34}$ Cresswell continued to be sporadically present in John Mulgan's life in England, and as such John would have been well aware of Cresswell's antimodernism and his manifestos.

The manifesto, as Mary Ann Caws observes, 'makes an art of excess', being 'a document of an ideology, crafted to convince and convert'. ${ }^{35}$ Central to the manifesto is what Caws terms 'the manifesto moment' which is its positioning 'between what has been done and what will be done, between the accomplished and the potential, in a radical and energizing division', a moment of crisis expressing 'what it wants to oppose, to leave, to defend, to change. ${ }^{36}$ I argue that Cresswell's manifestos find a strange companion in John Mulgan's writings with both Man Alone and Report on Experience being in their own ways forms of the antimodern manifesto and both being expressions of an antimodern rural flaneur.

Man Alone, written in a sense of antipodean cultural exile, can be read as a manifesto taking as its antihero an antimodern flaneur. ${ }^{37}$ Johnson is an outsider. If Cresswell is the New Zealander roaming England, Johnson is an Englishman roaming New Zealand, yet both are scarred by war, being members of what in Europe and North America was termed 
the lost generation. Brought up on a farm, Johnson flees the limited attractions of Auckland for the countryside and in doing so is described as joining the scarce ranks of good men. ${ }^{38}$ After three years of unthinking existence on the factory-like dairy farm, Johnson becomes the true antimodern rural flanuer, firstly voyaging to the central plateau with Scotty and then heading north where, wandering by boat with Pederson, he expresses the manifesto claim: 'There isn't any better country than this, not where a man can go about and get work, and stop when he wants to, and make money when he needs it, and take a holiday when he feels ready for one'; and later, down in the Wairarapa noting: 'It had always been a lucky country, a country where, if a man were well and strong, he could wander about and live well and eat well, where everybody was your friend in a hard, casual way, where a man tramping the roads in the back country could be sure of a night's rest and a meal wherever he stopped. ${ }^{39}$

Towns however are places of restriction and suffering, similar to work camps that 'play hell with men'. ${ }^{40}$ In town, walking becomes a purpose, especially so in the Queen Street march that becomes the riot that Johnson flees from eventually coming to reside in the countryside with Stenning. Here Johnson undertakes his fatal affair with Rua, who herself is symbol of the antimodern alternative for the urban Pakeha male. The flanerie becomes more focused, yet is like all flaneurs undertaken with a critical mind, walking against the society, its values and identities. After killing Stenning, Johnson undertakes internal exile fleeing into centre of countryside as a type of antimodern pioneer and crosses the desert plateau - where there are echoes of antimodern travellers - and then enters the primitive bush: '... surrounded and drowned in the hills and bush, safe and alone and submerged.' The bush is like a womb where he becomes a type of Rousseauian natural man. In fact the only other place that he feels the same is later in the central urban metropolis of London wherein the rural flaneur experiences being a modern flaneur: "He liked London. It was pleasant to wander about amongst so many people. There were so many people that no one cared for individuals. It was as lonely and impersonal as living in the bush ... [the] feeling of belonging to the whole world and to no one place. ${ }^{42}$

When Johnson leaves New Zealand he returns to the English countryside, but with the onset of industrialized agriculture, which is turning the countryside into a rural factory, he becomes restless and wanders again, finally seeking meaning in Spain: 'There was a desire in him now for a life that would give warmth and meaning to these memories before he grew too old, for a life active, but with good food and good drink, and men moving, making something together. ${ }^{43}$ Johnson is the expression of a non-poet's progress, yet also someone who is present without leave, seeking refuge from an ersatz modernity as a rural flaneur.

\section{Reporting the antimodern experience}

Man Alone is a type of fictional dry-run for what becomes Mulgan's antimodern manifesto: Report on Experience. This reporting of experience lies central to the flaneur and as Jack Bennet notes in his introduction: 'It is significant that many of his best friends were roving journalists, whose casual way of life appealed to him and who could supply him with the fresh, uncensored impressions that he required in the incessant process of forming his own opinions'. ${ }^{44}$ That this book is a manifesto is made explicit in a letter from John Mulgan to his wife Gabrielle dated 15 March 1945: 'The fact that one has deep convictions about people \& society \& the way the world should be made to exist for us, doesn't mean that one can write a good book. ${ }^{45}$

And this manifesto impulse is evident as Mulgan begins his text: '.. but if one has something to set down that concerns the world that we know now'. ${ }^{46}$ Mulgan proceeds to elaborate his own version of the cultural nationalist problem: a too small population in a 
country too old and hard for humans to make an impact means New Zealanders 'are often wanderers and restless and unhappy men. ${ }^{47}$ Fleeing a country small, isolated and remote, 'They roam the world looking not for adventure but for satisfaction. ${ }^{48}$ Yet there is something antimodern to be salvaged, for: 'The virtues and values of the New Zealanders were not so much wrong as primitive, and to this extent useful in the current collapse of civilization. $^{49}$

Of course this could also be what I term a socio-cultural form of the pathetic fallacy, in which not the landscape, but rather the society and culture, and expressions therein, take on the mood and emotions of the observer. While we tend to isolate the pathetic fallacy to landscape, I believe that both individuals and societies actually extend it socio-culturally to those things that we also feel invoke and evoke our emotions. Mulgan's manifesto therefore becomes an expression of an antimodern pathetic fallacy, such as when he outlines his vision for New Zealand:

This country would have more people to share it. They would be hard-working peasants from Europe that know good land, craftsmen that love making things with their own hands, and all men who want the freedom that comes from an ordered, just community. There would be more children in the sands and sunshine, more small farms, gardens and cottages. Girls would wear bright dresses, men would talk quietly together. Few would be rich, none would be poor. They would fill the land and make it a nation. ${ }^{50}$

There are very similar sentiments elaborated in the plan he and John Platt-Mills developed to take 500 Czech-German Social Democrats into New Zealand in 1939: '... these are the finest people in the world. They are mostly brought up on farms but trained as artisans, wood-work, metal-work etc. They believe in democracy - which all Jews don't - to the extent that they've given everything up to try and keep some freedom. ${ }^{, 51}$

His imagined antimodern future is also as an alternative to contemporary Britain and so links back into that long history of colonial antimodernism of Wakefieldian settlements, and the boosterism of 'A Better Britain'. Mulgan's antimodernism takes different forms to Cresswell including being politically informed, celebrating a love of working on the land, and finally the experiencing the life of the partisan in Greece. For it was the war that gave Mulgan his meaning and hope: 'The search that we made for a political religion and belief had no happy meaning. While we searched for something that could be both creative and stable, war caught up on us again. ${ }^{52}$ War took him to the wilderness, of the desert and then to Greece driven by: ' ... this unquiet search for an idea ...' [that] there were deeper and unsolved questions of belief, of belief that is in the way men should live and how they should behave to one another. ${ }^{53}$ This it seems was resolved when with the partisans in Greece because: 'There was some quality in these people, as there is, I expect, in all simple peasant people, that was solid and indestructible. ${ }^{54}$

\section{Re-thinking the antimodern (flaneur)}

How then should we think about these antimodern flaneurs, who flaneur as much on the page as they do on the land? Reengaging with Versluis we can see that Cresswell aligns with 'Hard antimodernists [who] seek to leave modernity behind or to overthrow it, whereas those closer to the "soft" antimodernists [such as Mulgan] only criticize it or, if they are a bit stronger in aim, hope to transform modernity into something else.' For what makes both Cresswell and Mulgan antimodern is that creativity is their reaction to "a modern sense of alienation, loss, and fragmentation ... This reaction is at the heart of antimodernism. 55 
The tension Cresswell expresses and Mulgan echoes is the claim that the truth of the modern world for New Zealand is either to be found overseas in antimodern European culture or to be found here in the land(scape), something later echoed and remade with the addition of antimodern Maoridom by both McCahon and Baxter. Therefore these antimodern flaneurs also provide the manifestos of a type of antimodern Pakeha identity.

\section{Pakeha: A post-foundationalist identity...?}

I want to institute a counter-narrative taking its starting point from the challenge laid down in the post-foundational thought of Gianni Vattimo. For Vattimo, the death of God signals the birth of hermeneutics, for a post-foundationalist world enacts what he terms the age of interpretation. Arising in response to Nietzsche's aphorism 'there are no facts, only interpretations, and of course this too is only an interpretation', the age of interpretation is qualified as an age of 'not neutral but engaged knowledge because it is not placed at an ideal place that would claim to be external to the process. ${ }^{56}$ That is, hermeneutics is the expression of knowledge that is necessarily provisional and contested, because the hermeneutic event is not an objective event that we respond to by thought, but rather a transformative event that transforms our existence. ${ }^{57}$

Pakeha, as a condition of modernity, is an act of hermeneutics, a form of participant knowledge that by its very self-expression is a type of engaged knowledge. Claiming to be Pakeha is an act of self-interpretation that transforms the interpreter, for it is giving up the foundational, essentialist claim of New Zealander by engaging in an interpretative strategy similar to Charles Winquist's positioning of postmodern theology whereby Pakeha, as an interpretative strategy 'has had to rethink its warrant without authority from outside its own productive formulation'. Pakeha, as an interpretative strategy is therefore, like theology, 'a textual production that is always in the middle of existing discourses' that, because it is anti-foundational is a claim without special privilege', a deconstructive reading making, as Winquist notes, 'all existing texts unsafe, ${ }^{58}$. Pakeha is thus a selfinterpretative claim against any claims for either a collective, foundational New Zealand identity or an essentialist European New Zealander identity. However, it must also seek to disestablish foundationalist or essentialist claims that Pakeha is either primarily an expression of birthright or skin-colour. A further tension is that Pakeha is too often situated in terms of an antimodern crisis of loss - the loss of coming here, the loss of staying here, the loss of being over there but longing come back to here, the loss of not being Maori, the loss of not being European, the loss of being modern: in short too often a form of antimodern negative identity politics.

Yet if Pakeha are to be modern, we need to remember the flaneur is the one who 'wanders the streets, ambling through its passages, and revealing its undisclosed secrets'; they are also the one who when, 'distracted among a crowd', makes 'unconscious and unwitting connections' and, so in the process, 'reveals the mythological secrets of society. ${ }^{59}$ The trouble is, in this most urban and suburban of nations, for Pakeha the streets are perhaps too often and for too long rural roads wandered by men alone, present without leave, reporting on antimodern experience, writing manifestos of the pathetic fallacy.

\footnotetext{
${ }^{1}$ Michel de Certeau, The Practice of Everyday Life. Translated by S.F. Rendall, Berkeley, 1984, p.103.

${ }^{2}$ Keith Tester, 'Introduction', in K. Tester, ed., The Flaneur, London; New York, 1994, p.7.

3 Zygmunt Bauman, 'Desert Spectacular', in K. Tester, ed., The Flaneur, London; New York, 1994, pp.138-157.

Anke Gleber, The Art of Taking a Walk: Flanerie, Literature, and Film in Weimar Germany, Princeton, 1999, p.132.

${ }_{5}$ Walter Benjamin, The Arcades Project, R. Tiedemann, ed., Translated by H. Eiland and K.
} 
McLaughlin, Cambridge; London, 1999/2002, p.417.

${ }^{6}$ Erik Olssen, 'Towards a New Society', in W.H. Oliver, ed., The Oxford History of New Zealand, Wellington, 1981, p.253. Or as Graham Dunstall notes: 'In 1936 a third of the population was rural, by 1976 the proportion was one-sixth.' Graham Dunstall, 'The Social Pattern', in W.H. Oliver, ed., The Oxford History of New Zealand, Wellington, 1981, p.401.

${ }^{7} \mathrm{https} / / / \mathrm{www} . c i a . g o v /$ library/publications/the-world-factbook/fields/2212.html.

${ }^{8}$ David Wyatt, The Fall into Eden, Cambridge, 1986, p.206.

${ }^{9}$ Francis Pound, 'Two Centuries of New Zealand Landscape', Art New Zealand, 55 (1990), p.83.

${ }^{10}$ O. Burke Long, Imagining the Holy Land. Maps, Models and Fantasy Travels, Bloomington; Indianapolis, 2003, p.1. For discussion of concept see J.K. Wright, Human Nature in Geography, Cambridge, 1966.

${ }^{11}$ McKenzie Wark, Dispositions, Applecross; Cambridge, 2002, 20 April 2001 11:18 EST.

${ }^{12}$ Stephen Turner, 'In Derrida's Wake: Why I Can't Think Where I am', in Laurence Simmons and Heather Worth, eds., Derrida Down Under, Palmerston North, 2001, p.70.

${ }^{13}$ Sven Birkets, 'Walter Benjamin, Flâneur: A Flanerie', The Iowa Review, 13, 3/4 ( 1982/1983), p.167.

${ }^{14}$ Benjamin, p.420.

${ }^{15}$ Birkerts, p.165.

${ }^{16}$ Ibid.

${ }^{17}$ I wish to thank the anonymous reviewers for their thoughtful and helpful readings and comments. I owe this distinction between local theory and local practice to reviewer 2 .

${ }^{18}$ Again I acknowledge the comments of reviewer 2, who asked the question of designation and difference.

19 Donald W. Meinig, 'Introduction', in Donald Meinig, ed., The Interpretation of Ordinary Landscapes, New York; Oxford, 1979, p.3.

${ }^{20}$ Francis Pound, Frames on the Land, Auckland, 1983. It was not so much the title that proved controversial as his dismissal of the 'mythic' notion that there was such a 'thing' as a specific 'New Zealand Light' which had previously (and many claim still does) created a 'special way of seeing' and representation in New Zealand Art.

${ }^{21}$ Wyatt, p.209.

22 'To R.A.K. Mason, 22 March, 1931', in Lauris Edmond, ed., The Letters of A.R.D. Fairburn Selected and Edited by Lauris Edmond, Auckland, 1981, p.46.

, in,

${ }^{23}$ Birkets, pp.165-166. For discussion of concept see Geoffrey Hartmann, Criticism in the Wilderness. The Study of Literature Today, New Haven, 1980.

${ }^{24}$ Of course such rehabilitation is often fragmentary; on the one hand he has become central to the queering of New Zealand literary history, yet to see him as solely or centrally a queer writer is, I would argue to reduce Cresswell to a singularity he would reject. Whilst taking seriously the queer Cresswell, the centrality of Cresswell as a cultural question and oxymoron has been spearheaded by the work of John Newton, who in an email to me notes the smallness of the field referring to 'the discerning Cresswellian (all 2 of us!).' Letter, Newton to Grimshaw, 1 October, 2011. Patrick Evans, The Long Forgetting, Christchurch, 2007, pp.125,127.

${ }^{25}$ Walter D'Arcy Cresswell, Present Without Leave, London, 1939, pp.180-181.

26 'To C.E. Carrington, June 3, 1923', in Walter D'Arcy Cresswell, The Letters of D'Arcy Cresswell Selected by Helen Shaw, Christchurch, 1971, p.28.

${ }^{27}$ Allen Curnow, 'Introduction', in The Penguin Book of New Zealand Verse Selected with an Introduction and Notes by Allen Curnow, Harmondsworth, 1960, p.316.

${ }^{28}$ Charles Brasch, Indirections: A Memoir 1909-1947, Wellington, 1980, pp.310, 359.

${ }^{29}$ Walter D’Arcy Cresswell, The Poets Progress, London, 1930, p.110.

${ }^{30}$ Cresswell, Present Without Leave, dedication page.

${ }^{31}$ Ibid., p.179

${ }^{32}$ Arthur Versluis, 'Antimodernism', TELOS, 137, (2006), p.96.

${ }^{33}$ Charles Brasch, 'Notes', Landfall, 14, 2 (1960), p.117.

${ }^{34}$ Cresswell, Present Without Leave, p.253

${ }^{35}$ Mary Ann Caws, Manifesto: a Century of isms, Lincoln, 2001, p.xx. Ibid., p.xvii.

${ }^{36}$ Ibid., pp.xxi, xxiii.

${ }^{37}$ The distinction and issues between a self-chosen cultural dislocation of the exile and the imposed and enforced political exile is noted, but is a separate discussion to this article. Mulgan was no political exile, but I would argue he took part in that wider sense of cultural exile central to modernism. As 
noted by the comments of reviewer 2, there are ethical issues in such use of exile in the face of the experiences of political exiles. Yet I would counter-argue that such use of cultural exile is not just a metaphor, but rather a type of existential labelling and identity that is, in its own way very political. For those who wish to follow up (and perhaps argue with) this possibility, I refer them to Mike Grimshaw, Bibles and Baedekers: Tourism, Travel, Exile and God, London, 2008.

${ }^{38}$ John Mulgan, Man Alone, Hamilton, 1960, p.17.

${ }^{39}$ Ibid., p.36.

${ }^{40}$ Ibid., p.83.

${ }^{41}$ Ibid., p.139.

${ }^{42}$ Ibid., p. 200.

${ }^{43}$ Ibid., p. 196.

${ }^{44}$ Jack Bennett, 'Foreword', in John Mulgan, Report On Experience, Auckland, 1967, p.vi

${ }^{45}$ Mulgan quoted by Bennet in Ibid., p.xi.

${ }^{46}$ Mulgan, Report On Experience, p.1.

${ }^{47}$ Ibid., p.3.

${ }^{48}$ Ibid.

${ }^{49}$ Ibid., p.7.

${ }^{50}$ Ibid., p. 15.

51 Mulgan quoted in Vincent O'Sullivan, Long Journey To the Border. A Life of John Mulgan, Auckland, 2003, p.206.

${ }^{52}$ Mulgan, Report on Experience, p.33.

${ }^{53}$ Ibid., pp.71, 82.

54 Ibid., p. 105.

${ }^{55}$ Versluis, p. 106.

56 Gianni Vattimo, Beyond Interpretation, the Meaning of Hermeneutics for Philosophy, Cambridge,1997, p.6. Gianni Vattimo, After Christianity, New York, 2002, p.15.

${ }^{57}$ Ibid., p.13.

${ }^{58}$ Charles E. Winquist, 'Postmodern Secular Theology', in Clayton Crockett, ed., Secular Theology: American Radical Theological Thought, London; New York, 2001, p.28. Winquist, p.29.

${ }^{59}$ S. Brent Plate, Walter Benjamin, Religion, and Aesthetics: Rethinking Religion through the Arts, London; New York, 2005, p.131. 